School of Finance

University of St.Gallen

INTERNATIONALIZATION AND FIRM VALUATION: NEW EVIDENCE FROM FIRST OFFSHORE BOND ISSUANCES OF US FIRMS

Nebosja Dimic

Vitaly ORLOV

WORKING PAPERS ON FinANCE NO. 2018/3

SWISS INSTITUTE OF BANKING AND FINANCE (S/BF - HSG)

FEBRUARY 2018 


\title{
Internationalization and firm valuation: New evidence from first offshore bond issuances of US firms*
}

\author{
Nebojsa Dimic ${ }^{\dagger}$ and Vitaly Orlov
}

\begin{abstract}
Does internationalization affect firm valuation? To answer this question, literature mainly considers firms from around the world internationalizing by issuing equity in the USA, whereas the current study focuses on US firms that internationalize by issuing debt in overseas markets. This paper provides evidence on theories of internationalization and capital structure, finding that overseas corporate debt offerings have a positive short-term effect on US firms' valuations. The effect varies in firm characteristics, timing, and the location of the issue. Additionally, firms with a strong need for external funds and growth prospects accelerate their offshore public debt market entry.
\end{abstract}

JEL classifications: G15; G32; F36

Keywords: Internationalization; Debt Structure; Segmentation; Tobin's $q$

\footnotetext{
*Authors are grateful for the comments and suggestions of Elias Rantapuska, Martha O’Hogan, Mikko Leppämäki, Marku Kaustia, Matti Keloharju, John Broussard, Michael Bowe, Adri De Ridder, Matthias Merkel and the participants of the 2017 Southern Finance Association Annual Meeting, the 2016 Graduate School of Finance (GSF) and the Finnish Doctoral Program in Economics (FDPE) Workshop in Finance (Aalto University) and 15th INFINITI Conference on International Finance, and University of Vaasa. The paper was partially written while Nebojsa Dimic was a visiting scholar at Alliance Manchester Business School. Nebojsa Dimic gratefully acknowledges financial support from the OP-Pohjola Group Research Foundation (grant 201600054) and Marcus Wallenberg foundation.

${ }^{\dagger}$ Corresponding author. University of Vaasa, Department of Accounting and Finance, P.O. Box 700, FI-65101 Vaasa, Finland; Tel.: +358 45104 7707. E-mail address: dnebojsa@uva.fi (N. Dimic)

$\$$ University of St. Gallen, Swiss Institute of Banking and Finance, Unterer Graben 21, CH-9000 St.Gallen, Switzerland; Tel.: +41 71224 7003. E-mail address: vitaly.orlov@unisg.ch (V. Orlov)
} 


\section{Introduction}

What are the causes and effects of internationalization? To answer this question, the available literature mainly focuses on firms from around the world internationalizing by issuing equity in the USA. At the same time, trends from recent decades indicate an increasing number of corporate debt offerings and a growth in the volume of capital raised by US firms worldwide. The current paper examines US firms that internationalize by issuing straight dollar denominated debt in overseas markets and the effects of such financial internationalization activities.

Recent evidence indicate that the competitiveness of the US equity and bond markets relative to overseas markets has weakened (see, e.g., Zingales, 2007; Peristiani and Santos, 2010). Over the last two decades, international corporate bond markets have been growing at a faster rate than the US bond market. ${ }^{1}$ This is most commonly attributed to the financial development, liberalization, and disintermediation of the major overseas markets along with the adverse influence of the enactment of new regulations (e.g., the Sarbanes-Oxley Act of 2002) on the competitiveness of the US capital market. Studies by Engel, Hayes, and Wang (2007), Marosi and Massoud, (2007) and Berger, Li, and Wong (2005) suggest that costs arising from SOX discourage firms from listing in the USA and cause US firms to raise capital on overseas exchanges. Peristiani and Santos (2010) show that the choice of US firms to change the market of debt financing from the domestic to the foreign is driven by the decreased US bond market competitiveness reflected in relatively higher underwriting costs.

The extant literature on international corporate finance mainly directs attention to the effects of actions to raise foreign equity capital and focuses on firms from markets around the

\footnotetext{
${ }^{1}$ In the mid-1990s, the total volume of corporate bonds issued in the US (\$564 billion in 1995) was nearly twice the volume of all other bond markets combined. The disproportionate growth of US and international bond markets resulted in equal estimates of around \$1.5 trillion in mid-2000s. Over the recent decade, as indicated in Thompson Reuters Debt Capital Markets reviews, this trend continued, and the 2015 figures record the US share of corporate bond issuance totaling $\$ 2.6$ trillion, which is less than half of global debt issuance (\$5.3 trillion) in 2015.
} 
world internationalizing in the USA and other developed markets by issuing equity. However, raising debt in international markets is a far more important source of capital for firms than issuing equity. Consequently, debt markets tend to be internationalized to a larger extent than equity markets (Gozzi et al., 2010). Accordingly, trends relating to the raising of foreign capital over recent decades indicate that financial internationalization is becoming a multidirectional phenomenon with an increasing number of US firms issuing securities (primarily bonds) in markets worldwide. Over the last three decades, the volume of straight dollar denominated corporate bond issuance by US firms on overseas exchanges has grown from $\$ 35$ billion in the 1980s to $\$ 50$ billion and $\$ 1$ trillion in the 1990s and 2000s respectively. The average number of issuances per year almost doubled over these years from 46 in the 1980 s to 85 in the 2000 s. However, previous literature offers little evidence on the causes and effects of US firms' foreign capital raisings; moreover, there are sharp theoretical and empirical disagreements over the general impacts of internationalization on individual firms. This paper attempts to fill the above-mentioned gap.

This is the first study to focus on US firms that raise debt capital as their first international activity in major overseas markets. The current paper contributes to the international corporate finance literature in several ways. First, this paper extends the growing literature on the link between initial public debt issues and the various consequences of debt structure change. Given the focus in that stream of literature, the initial shift to public debt financing is shown to be one of the most informative occurrences of the capital raising events. In contrast to previous studies that mainly focus on domestic bond IPOs, the current research provides new insight on the validity of some debt structure theories by focusing on the unique information content of overseas initial public debt offerings. An initial bond offering in a foreign market embodies an important change in the nature of a firm's debt. Second, an initial public debt issue in a foreign market also offers exclusive opportunities to investigate the impact that financial 
internationalization has on firm value. This study relates to the two conflicting theories explaining the causes and effects of firms' internationalization: segmentation and bonding theory. Previous studies, however, focus on the internationalization of emerging market or other developed market firms into the US markets, while tending to overlook the reverse situation. In this regard, this paper provides an important addition to the debate through its unique setup, as US firms have the most advanced corporate governance systems in the world. ${ }^{2}$ Another contribution of this study is that our empirical investigation provides new evidence on the determinants of a firm's decision to enter the public bond market. This is the first study to identify the characteristics that affect the timing of firms' decisions to undertake an initial public debt offering abroad.

This paper uses a comprehensive sample on initial debt issues in overseas markets spanning a 31-year period and portrays the offshore bond IPO market. The dynamics of all offshore bond issues are contingent upon the state of the US economy, similar to the distribution of seasoned straight debt offers in the domestic market, while the number of foreign debt IPOs are more evenly distributed throughout the sample. Both the average volume and average number of offshore bond IPOs have been steadily growing throughout the sample years. The most recent decade is characterized by both an increasing number of relatively small and young firms that undertake a bond IPO overseas and by an increase in the variety of markets US firms internationalize into.

The main finding of this the study is that internationalization has a positive short-term effect on US firms' valuations, as measured by Tobin's $q$. Accordingly, the initial issuance of straight debt overseas conveys positive information to the market. We observe significant positive anticipatory and impact valuation effects around the internationalization dates, which subsequently diminish in the longer term. The results withstand various robustness checks, and

\footnotetext{
${ }^{2}$ For more details see Tables 2 and 6 in La Porta et al. (2002)
} 
the positive valuation effect does not vary in the face of the introduction of controls for the firms' size, growth prospects, and leverage; on the industry of the issuer; on the alternative measure of valuation (the relative Tobin's q); and cannot be explained by the market timing theory.

The results also indicate that the benefits of internationalization for US firms differ sharply depending on the financial condition of the firm prior to issuance and the specific market it internationalizes into. In particular, we find that firms with low liquidity prior to the internationalization, as measured by quick ratio, have a negative short-term effect on valuation after the offshore bond IPO, while more liquid firms experience a short-term increase in their valuation. Further, we find that the valuation of more established and relatively larger firms is less affected by offshore bond IPOs than the valuation of other firms. Consistent with reputation-building theories, the valuation change due to the bond IPO is negatively related to the information asymmetry of the firm. The location of the market where US firms issue debt also affects the results. The positive short-term effect on Tobin's $q$ is conditional upon the US firms raising debt in other developed markets.

The results on the determinants of a firm's decision to enter the public bond market suggest that firm's financial conditions prior to issuance affect the timing of the decision to undertake an initial public offer of straight debt overseas. Specifically, firms that have made significant investments prior to the initial debt offer and firms with greater need for external funds due to lower profitability and liquidity are more likely to undertake bond financing in the foreign markets earlier than other firms would.

This study adds to the literature in several important ways, which we discuss in the following section. On a broader level, this paper extends the ground covered in previous literature by examining US firms internationalizing in foreign markets by issuing debt. Specifically, the current paper brings together several important segments of literature, including, debt structure 
theories, theories of financial internationalization, literature on the determinants of the decision to access the public debt market, and contributes to them along several dimensions.

The remainder of the paper proceeds as follows. The next section presents the theoretical background and the analytical framework underpinning the study, while relating our results to the existing theories and empirical evidence. Section 3 describes the dataset, the data collection process, the methods used for the empirical analysis, and provides basic statistics. Section 4 presents the supplementary analysis where we investigate potential determinants of the decision to enter the foreign public bond market. Section 5 turns to the relationship at the center of the study and examines the effect of internationalization on firm valuation. Section 6 concludes the paper.

\section{Related literature and background ideas}

First, this paper contributes to several prominent capital structure theories by providing new empirical evidence on the valuation effects of overseas corporate debt offerings. The findings of this paper support debt structure theories suggesting that the issuance of straight debt conveys positive information to the market and, therefore, positively affects the valuation of the firm (Kraus and Litzenberger, 1973; Jensen and Meckling, 1976; Heinkel, 1982; Myers and Majluf, 1984; and Stein, 1992). Collectively, these theories suggest that an issuer should benefit from a valuation increase in response to news about a debt offering. That positive revaluation may be due to either balancing the agency costs of debt against the agency costs of equity, the reduction of moral hazard behavior on the part of managers, or simply the capitalization of new valuable investment opportunities. ${ }^{3}$ In altering the private-public debt mix, raising capital

\footnotetext{
${ }^{3}$ Note, however, that theoretical literature offers conflicting predictions on the effects of corporate bond offerings (mainly seasoned offers) on firm's valuation. In contrast to the aforementioned papers, theoretical works of Modigliani and Miller (1958) and Miller (1977) suggest no value-related effects to capital structure change, while models of Miller and Rock (1985), and Diamond (1991) predict negative reaction to debt offerings.
} 
overseas appears to change the agency costs of debt through managerial incentives, the level of monitoring, and information asymmetry (Ross, 1977; and Heinkel, 1982), and, also, embed signaling through access to high-quality lenders (markets) as well as greater information provision (Titman and Trueman, 1986). The empirical literature on the effects of corporate bond issues offers diverse evidence on the equity wealth change in response to the issues. ${ }^{4}$ The first study to examine valuation effects of initial bond offerings is that of Datta et al. (2000), who suggest that stock price responds negatively to a debt IPO announcement. Although, the current paper relates to the broad literature on whether corporate bond offerings lead to shareholder value creation, we do not examine the stock price reaction to bond IPOs, but instead focusing on the cross-firm implications of access to international bond markets, and the consequences of financial internationalization.

This study also adds to the debate around theories of firm internationalization. Previous studies like Foerster and Karolyi (1999), Domowitz et al. (1998), Karolyi (2006), Levine and Schmukler (2006) and Gozzi et al. (2008) focus on the internationalization of firms from emerging markets or from other developed markets into the US equity markets through the issue of depositary receipts and raising equity capital through private or public placements. This paper extends the ground covered in previous literature by examining US firms internationalizing into foreign markets through issuing debt.

The findings of this paper indicate that internationalization improves the firm's valuation, therefore contributing to the literature on segmentation theory. That theory suggests that financial internationalization overcomes barriers to international capital flows and potentially provides firms with cheaper capital, which consequently improves their valuation (Black, 1974; Solnik, 1974; Errunza and Losq, 1985; Stapleton and Subrahmanyam, 1977; Alexander et al.

\footnotetext{
${ }^{4}$ For an overview of existing empirical evidence on stock market reactions to bond offerings see Table 1 in Klein (2017).
} 
1987; Domowitz et al., 1998; Pagano et al., 2002; Gozzi et al., 2010). Further, our results confirm segmentation theory because we only find a short-term positive effect where valuation rises in the period before and during the internationalization and then it falls back to around its original level (Tobin and Brainard, 1977; La Porta et al., 2002; Lan and Wang, 2004; Durnev and Kim, 2005; Caprio et al., 2008; Albuquerque and Wang, 2008).

Furthermore, we show that the valuation effect is conditional upon the US firms raising debt in other developed markets, and the effect is large in magnitude for relatively small and young firms. This evidence is consistent with bonding theory, bonding theory argues that firms issuing securities abroad bond themselves to better corporate governance practices, thus improving investor protection and reducing agency problems, which, in turn, is amplified for less prominent firms (Stulz, 1999; Coffee, 2002; Reese and Weisbach 2002, Doidge et al. 2004; Gozzi et al. 2008; Gozzi et al. 2010). ${ }^{5}$

Additionally, the findings that the valuation of older and relatively large firms is affected less by offshore bond IPOs is consistent with Diamond's (1991) reputation-developing assertion, suggesting less information asymmetry for more established firms. In a similar manner, this finding supports Chaplinsky and Ramchand's (2000) argument that a firm's market value correlates positively with the number of investors who know about the firm. Global issuance of securities thus reduces the information costs by raising the profile of a US firm with stakeholders around the world.

Next, this study contributes to the literature on determinants of the bond market entries. The extant literature on choices of funding sources and effects of firms' switching to bond financing devote little attention to the distinct characteristics of firms that decide to enter the bond market for the first time, or to the timing of that decision. The first paper to find that firm-specific traits

\footnotetext{
${ }^{5}$ Note, however, that some studies question the very existence of the relationship between internationalization and the improved governance system of a firm, thus disregarding the motivation behind bonding theory (Licht, 2003; Pinegar and Ravichandran, 2003; Siegel 2004).
} 
increase the likelihood of undertaking a debt IPO was that of Datta et al. (2000), who suggest that large firms and firms with greater financial needs are more likely to enter a public bond market than others are. Accordingly, Hale and Santos (2008) find that firms with these characteristics, in addition to high creditworthiness and strong reputation, tend to undertake a domestic bond IPO earlier than others do. Our finding of firm's financial conditions influencing the decision to undertake an initial public offering of straight debt supports the conclusion of Hale and Santos (2008) such that a greater need for external funds and creditworthiness accelerate public debt market entry. While we cannot confirm that firm size necessarily affects the timing of the firm's decision to access the international public bond markets, we do find similarities between other key determinants of the decisions to undertake offshore and domestic bond IPOs.

Lastly, this paper shows that the dynamics of the offshore bond IPO market as well as the portrait of a typical issuer are similar to those of corporate debt offerings in the US market. Evidence on domestic bond offerings, like that provided by Eckbo (1986), Johnson (1997), Krishnaswami et al. (1999), and Cantillo and Wright (2000) collectively suggests that large and creditworthy firms operate with more debt and are therefore more prone to issue bonds. The characteristics of the firms in our sample broadly supports this notion; however, we observe that overseas public debt issues are becoming increasingly accessible for younger firms. Extemporaneously we can relate this to the increasing pace of globalization in capital markets, also supported by the evidence on equity cross-border listings in Karolyi (2006). Lastly, descriptive evidence also supports the notion of business cycle dependent clustering of offerings, as noted by Ljungqvist (1995), Helwege and Liang (1996), and Santos (2006), such that the fluctuation in the number of bond offerings over the years is contingent on the state of the US economy. The following section details the properties of the sample. 


\section{Data, methodology, and sample design}

In this section, we describe the data, the sample, and the empirical strategies used to explore the determinants of a firm's decision to issue bonds abroad, and to examine the impact of financial internationalization on a firm's valuation.

\subsection{Data}

In the empirical analysis, we use data on (i) dates of offshore bond IPOs by US firms, (ii) issue characteristics, (iii) firm-level data on valuation, and (iv) firm-specific characteristics. We rely on three sources to identify our sample and to obtain the data for the empirical analysis.

First, we identify the US firms' international activities by utilizing the data from the Thomson Reuters SDC Platinum database. SDC Platinum is regarded as the most comprehensive database on global security issues (Gozzi et al. 2008). Specifically, we collect (i) the dates of first internationalization activity: the initial offshore bond offerings from publicly traded US firms, (ii) the principal amount of the issues, and (iii) the country and the exchange where the issues are listed. ${ }^{6}$ The firm is included in our sample if it at least once raises debt capital offshore by issuing straight debt denominated in US dollars and has not previously issued any other securities abroad. ${ }^{7}$ In a time-series dimension, the US firm is classified as international from the moment it raises debt capital abroad for the first time.

The sample of US firms is then screened against the Compustat database for the data availability on valuation and other firm-level traits. We pay particular attention to whether the

\footnotetext{
${ }^{6}$ Please note, data on international debt capital raising is not as complete as that of domestic bond IPOs, so we were not able to obtain the complete information set for some issue characteristics like filing dates or underwriters.

${ }^{7}$ Here and throughout the paper, straight debt is an issue defined by the SDC Platinum database as a straight bond, which is a non-convertible bond, note or debenture. However, SDC Platinum does not report all of the relevant features of a debt issue, some of the issues classified straight bonds, may simply be instruments that are more complex. Therefore, we manually screened all potential sample entries and eliminated those that do not match a simple straight bond criteria (in total 7 issues were excluded). Finally, we make sure that our sample consists of firms that internationalize only by issuing U.S. dollar denominated debt. This eliminates potential alternative explanations of our results, such as hedging motives, currency inflows/outflows matching and other exchange rate risk related arguments.
} 
timing of the issue and the impact on valuation differs by firm characteristics such as liquidity ratio, indebtedness, profitability, growth opportunities, and size. In addition, we rely on Compustat to determine a firm's age. Finally, we gather industry related information and, in the empirical analysis, exclude financial firms from our sample. ${ }^{8}$ Our sample is limited to those firms with available data on each of the required variables.

\section{Insert Figure 1}

Finally, we use CRSP to eliminate firm subsidiaries from our sample, and to control for name changes and mergers or acquisitions that occurred over the time span of this study. After the matching procedure, our final dataset provides annual observations of 168 US firms (198, including financial firms) that internationalized by raising debt capital abroad for the first time during the period from January 1984 until December 2014.

\subsection{Methodology and variables' definition}

The empirical strategy of our study is determined by the two objectives of our analysis: (i) to identify the determinants of the firm's decision to issue bonds abroad for the first time; and (ii) to evaluate the impact of the internationalization on firm valuation. This section outlines the two approaches.

First, we investigate the possible impact of the set of explanatory variables on the timing of the initial international bond issues. In other words, we study how various firm characteristics affect the timing of a firm's decision to issue bonds offshore during its lifetime. We focus on the timing of the event of interest and conduct a survival analysis. In our framework, the

\footnotetext{
${ }^{8}$ In doing so we rely on prominent studies, that suggest that the valuation of financial firms can be determined differently due to high leverage and difference in regulation environments (see, e.g., Gozzi et al., 2008).
} 
outcome variable (exposure time) is the firm's age and the event (failure) is the firm's decision to issue bonds abroad for the first time. The hazard function then pinpoints the probability that the offshore bond IPO will occur during the current year, given that the firm has not done so (survived) up to the year in question. Once the event occurs, the firm exits the sample.

In our survival analysis, in a similar vein to Hale and Santos (2008), we estimate Cox proportional hazards regression models (Cox, 1972). This semiparametric model makes fewer assumptions than do parametric models (e.g., with Weibull or Gompertz distributions). ${ }^{9}$ For instance, it makes no assumptions about the shape of the hazard function and allows easy interpretation of hazard function and explanatory variables. The hazard function takes the form:

$$
h(t)=h_{0}(t) e^{X^{\prime} \beta},
$$

The outcome variable in our models is the firm's age, which is computed by subtracting the year of the first appearance in the Compustat from the year of each observation in our sample (available from 1950). Alternatively, for robustness purposes, we redefine the age variable using the CRSP appearance date and trace the firm age back as far as 1925. In our survival models, the outcome variable is estimated against the set of explanatory variables that can be broadly grouped as follows: the firm's growth opportunities, liquidity, creditworthiness, and the bond market conditions. ${ }^{10}$ The explanatory variables are computed and followed from the year the firm appears in Compustat until the year prior to the intentional bond issue. The positive $\beta$ coefficient then indicates that the increase in explanatory variable $\mathrm{X}$ leads to greater hazard that, in turn, translates into a greater probability that the event will occur; or in our case, a shorter period before the firm decides to issue bonds abroad.

\footnotetext{
${ }^{9}$ For robustness purpose, we estimate parametric models with Weibull and Gompertz distributions as well. Results are similar to their counterparts in Table 2.

10 Those explanatory variables are Tobin's q, Investments-to-Assets, Quick ratio (cash and short-term investments to current liabilities), ROA, Leverage, Size, Offshore bond market (total number of offshore bond issues), and the Recession indicator (as defined by NBER).
} 
The second objective of the paper is to evaluate the impact on a firm's valuation of an internationalization conducted by issuing bond IPOs abroad. In order to address this objective, we estimate unbalanced panel regressions and report standard errors clustered at the firm level. Further, each of the models and specifications includes firm $\left(n_{j}\right)$ and year effects $\left(\tau_{t}\right)$. We examine the dynamics of the impact of the US firms' offshore bond issue activity on a firm's valuation, by including the anticipatory, impact, and intermediate dummy variables in our models. Finally, the following regression is estimated:

$$
T_{i, t}^{I}=\alpha_{0}+\beta_{1} A n t_{i, t}+\beta_{2} \operatorname{Imp}_{i, t}+\beta_{3} \operatorname{Int}_{i, t}+\beta_{5} S_{i, t}+\beta_{6} S G_{i, t}+\beta_{7} L_{i, t}+\beta_{8} n_{j}+\beta_{9} \tau_{t}+\varepsilon_{i, t}
$$

$T_{i, t}^{I}$ stands for Tobin's $q$, which is the firm's $i$ valuation measure in time $t$. The superscript $I$ labels the firm as an international, which is a firm that raises debt capital abroad at some point over the sample period. The numerator of Tobin's $q$ is the market value of equity plus the book value of debt (calculated as the book value of assets minus the book value of equity) and the denominator is the book value of assets. Specifically, the book value of debt is calculated as the book value of assets minus the book value of equity. Similar definitions to Tobin's $q$ are used in La Porta et al. (2002), Doidge et al. (2004), and Gozzi et al. (2008). Following the aforementioned literature, we use the firm-specific characteristic that might affect the valuation of firms. To control for the firms' size and growth prospects, we collect the data on total assets and sales growth. We use sales instead of earnings because earnings are often volatile and easily manipulated.

$A n t_{i, t}$ is a dummy variable capturing the anticipatory effect of internationalization on the firm's valuation that equals one in the year before the first offshore bond issue by US firm and zero otherwise. $\operatorname{Im} p_{i, t}$ captures the impact effect of the internationalization and takes the value of one in the year of bond issue and zero otherwise, while $I n t_{i, t}$ represents an intermediate 
dummy variable that equals one for the year after the first offshore bond issue. To control for possible size effects, we include a variable of the logarithm of total assets $S_{i, t}$ of a firm $i$ in time $t$ in each model specification. We also control for the sample firms' growth prospects by including $S G_{i, t}$ that represents the growth rates of total sales. Next, we control for the firm's ability to meet its financial liabilities by introducing the leverage ratio $L_{i, t}$, which is calculated as the firm's total outstanding debt divided by the amount of shareholder equity. Finally, we also control for firms operating in financial and high-tech industries and check if the valuation effect changes upon the introduction of the state of the market, the industry of the issuer, and the alternative measure of valuation.

\subsection{Sample characteristics}

The sampling procedure provides a complete history of all offshore public debt offerings made by US firms over the period from January 1984 until December 2014. We identified a total of 1552 such issues over the 31-year sample period, of which 198 are internationalization issues, defined as an event of first offshore financial market entry by issuing public debt. Figure 1 depicts the distribution of offshore public bond issues over time. The dynamics of all offshore bond issues coincides reasonably well with the distribution of investment grade corporate debt offerings in the domestic market, such that the total number of bond offerings increases during the expansion periods in the US economy and drops around periods of recession. The distribution of new offshore public bond offerings is quite stable, with a few exceptions around the recession periods in the US economy, thus again being similar to the distribution of new bond issues in the domestic market. ${ }^{11}$

\footnotetext{
${ }^{11}$ See Santos (2006) for an overview of the US bond market during expansions and recession periods. For the total number of the new bond issues in the US over the years and other descriptive statistics, see, e.g., Hale and Santos (2008). Lastly, see NBER data for dates of business cycles in the US economy.
} 


\section{Insert Table 1}

Table 1 reports the statistics for the US firms that internationalized by raising public debt capital abroad for the first time during the period 1984-2015. As listed in Panel A, 198 firms internationalized over this period. The average size of first public debt offerings rose from $\$ 133$ million in the 1980 s to as much as $\$ 530$ million in the 2000s. Both the number of offshore offerings and the average amount of an issue gradually rose over the decades, indicating the increasing importance and improved accessibility of foreign debt markets. The typical firm in the sample issues straight debt in foreign markets in 3.4 of the 31 sample years, each year offering on average 1.8 sample issues of debt. All of the bond IPOs in the sample (if rated) are investment grade issues with a rating of $\mathrm{BBB}+$ or above. Panel $\mathrm{B}$ reports the (non-financials) firms' specific characteristics one year prior to the firm issuing public debt abroad and shows that firms that enter foreign debt markets are on average 28.7 years old, fairly large in terms of size, profitable, liquid, and sound. These characteristics are similar to those of new issuers of straight bonds in the USA, as documented by Hale and Santos (2008). ${ }^{12}$ Nevertheless, we observe variations in all of the firm traits that plays a role in the decision to undertake the bond IPO.

Insert Figure 2

Figure 2 (left-hand side) indicates that firms issuing public debt abroad follow the aggregate (offshore) bond market activity, thus, in most cases, prefer to issue bonds when the conditions are favorable. Covas and Den Haan (2011) show that corporate debt issuance is pro-cyclical

\footnotetext{
${ }^{12}$ Note, however, that in Hale and Santos (2008) sample period spans from 1972 until 2002 and covers 566 new issuers.
} 
with debt fluctuation being higher for the larger firms. In a similar vein, the firms in our sample exhibit cyclicality in their public debt issues. The right-hand side of Figure 2 shows the evolution of the average age of the offshore bond issuers over the sample period. The reduction in average age over the years suggests that undertaking a bond IPO overseas is becoming a strategy of young firms, perhaps because foreign debt markets are becoming more accessible, owing to the advent of lower entry barriers and costs in recent years.

It is worth noticing that issuing bonds abroad remains a relatively small source of debt capital for the US firms, for instance, overseas straight bond issues in US dollars in our sample account for only about two percent of all US corporate bond issuances over the period from 2010-2014 (\$207 billion of total of \$12.5 trillion). However, the proportion of offshore bond issuances is constantly growing, and in 2014 alone, US firms issued $\$ 102$ billion worth of dollar denominated bonds overseas, which amounted to around four percent of total issuances (\$2.5 trillion). Nevertheless, it is important to note that not only is raising international capital through debt issuances growing rapidly, but also that financial globalization in recent decades has made foreign markets more accessible to a wide range of firms. Moreover, bond issuance is the only way US firms raise capital on foreign markets, and monitoring the practice is therefore the only viable means to assess the effects of financial internationalization on US firms.

\section{Decision to enter the international bond market}

First, we investigate potential determinants of the decision to enter the foreign public bond market. We apply survival analysis and explore how firm-specific financial metrics and overall bond market conditions influence the timing of the firm's decision to issue bonds overseas. In this case, the outcome variable is the age of the firm, the event is the first issue, and the resulting 
coefficient- the hazard rate- is the instantaneous rate at which events occur due to changes in the associated explanatory variable, given no previous events.

The explanatory variables in our survival analysis cover a firm's growth opportunities, liquidity, creditworthiness, and the overall bond market conditions. In total, we investigate eight variables that have previously been found to affect a firm's decision to undertake an initial public offer of straight debt in the US market. In particular, Datta et al. (2000) shows that firm size and growth opportunities positively affect the probability of issuing public debt. Krishnaswami et al. (1999) and Cantillo and Wright (2000) show that more creditworthy firms issue relatively more public debt, while Hale and Santos (2008) suggest that both creditworthiness and demand for external funds, measured by the liquidity ratio, speed the firm's entry on to the public bond market. Lastly, a considerable body of research suggests that general condition of equity (see, e.g., Ljungqvist, 1995; Pagano et al., 1998) and debt (see, e.g., Helwege and Liang, 1996; Datta et al., 2000) markets affect the propensity of a firm to undertake an IPO.

\section{Insert Table 2}

Table 2, Models 1 through 7, reports the results of the survival analysis as coefficient estimates, such that a positive coefficient suggests that the increase in an explanatory variable leads to a greater hazard rate, or put simply, a shorter period before a firm decides to issue bonds abroad. ${ }^{13}$ Based on the discussion in the prior section, we estimate semiparametric Cox proportional hazards regression models. We use two proxies for a firm's demand for external

\footnotetext{
${ }^{13}$ While the sample characteristics offer reassurance of the reliability of the duration analysis, it is important to remember the possible duality in any interpretation of the result. Alternatively, in dynamic terms, a positive coefficient could also mean that firms with lower characteristics (e.g., smaller size) do not usually undertake bond IPOs, but as their financial characteristics evolve over time, the probability of undertaking an IPO increases.
} 
funds, Tobin's q and investments-to-assets. The size of the firm is defined as the natural logarithm of the book value of total assets. We use return-on-assets, leverage, and quick ratios to assess the financial condition of the sample firm at the time of issue. The recession and offshore bond market conditions variables are as defined above.

Firms with more investments (scaled by assets) tend to issue public debt abroad earlier. The coefficient of the investments-to-assets variable is positive and significant ( $t$-stat of 3.11), albeit Tobin's $\mathrm{q}$ in Model 1 does not influence the timing of a firm's decision to internationalize. This result is consistent with evidence that firms that have undertaken significant investments prior to the debt offer are more likely to issue a straight bond (see, e.g., Datta et al., 2000) and to do so earlier (see, e.g., Hale and Santos, 2008) than others that have taken no such action.

Models 3-5 show that return-on-assets and quick ratio, the proxies for the firm's profitability and financing needs, have a negative impact on the timing of the firm's entry to the public bond market. In other words, firms with a greater need for external funds, manifested in lower profitability and a lack of internal funds to cover current liabilities, wait for a shorter period before they undertake their first bond IPO overseas. Contrary to expectations and previous evidence on domestic initial bond offerings (see, e.g., Cantillo and Wright, 2000; Datta et al., 2000), both profitability and leverage have negative coefficient signs, but leverage is not statistically significant at the 10 percent level and we cannot reject the null hypothesis for any of the three models. On the contrary, finding that firms with less liquidity issue earlier is consistent with the evidence from domestic bond offerings (see, e.g., Hale and Santos, 2008).

Finally, in models 6 and 7, we investigate whether these findings hold when we include a firm's size and the bond market state in our jointly specified models. Not surprisingly, the size of the firm has a positive coefficient, such that larger firms issue bonds earlier, but it is not statistically significant. However, offshore bond market conditions, as defined by the total 
number of foreign bond IPOs, is a significant determinant of how quickly firm chooses to issue a debt IPO overseas. In conjunction with a negative coefficient on recession, this suggests that firms tend to issue bonds abroad when the market conditions are advantageous, which corroborates the evidence in Figures 1 and 2. Importantly, results on liquidity, profitability, and amount of investments hold in the jointly specified models.

In summary, the results suggest that firms that have made significant investments prior to the debt offer, and firms with lower profitability and liquidity, are more likely to undertake bond financing in foreign markets earlier than other firms that do not have these characteristics. In addition, firms seem to time overseas bond offerings to align with favorable market conditions.

\section{Valuation effects}

This section presents our main empirical results on the evolution of US firms' valuation around the dates of the financial internationalization. First, we illustrate the dynamics of valuation around the offshore bond IPO dates and provide a direct test of Tobin's $q$ before, during, and after the first internationalization activity of US firms. Next, we investigate if the relationship between the firms' first internationalization activity and the valuation holds when firms are differentiated by various characteristics prior to the internationalization event. Finally, we check if the valuation effect differs depending on the location and the timing of the issue.

\section{Insert Figure 3}

We illustrate the valuation dynamics by plotting the average Tobin's $q$ of all of the US firms included in the sample during the period of three years before and after the internationalization 
dates (Figure 3), where year 0 stands for the year of internationalization activity. Figure 3 illustrates an interim valuation effect of internationalization. Tobin's $q$ tends to rise before the initial offshore bond IPO, reaching its maximum in the year of actual issuance, before declining to around the pre-internationalization level. The following tables present the results of more formal statistical tests confirming that US firms' internationalization leads to a temporary increase in Tobin's $q$.

Insert Table 3

Table 3 shows that US firms internationalizing by issuing bonds abroad experience a shortterm increase in their valuation. To capture this dynamics we introduce a series of dummy variables that capture annual patterns around the dates of internationalization. Specifically, the dummy variable Anticipatory takes the value of one in a year prior to internationalization and zero otherwise, the Impact equals one in the year of the issue itself and zero otherwise, and so forth. In each of the models we control for a variety of relevant factors, include firm and year fixed effects and use standard errors clustered at the firm level. The control factors that potentially influence both Tobin's $q$ and the decision to internationalize are the firm's size (as measured by the logarithm of the firm's total assets); the logarithm of growth rate of sales; and the leverage ratio (computed as firm's total outstanding debt divided by the amount of shareholder equity). The sample consists of 168 firms and financial firms are excluded.

First, we find that an initial overseas bond issue positively affects the valuation of the firm. Models 2, 5, and 6 of Table 3 indicate that; regardless of the model specification, the Impact dummy variable enters positively and significantly, implying that internationalization by issuing debt overseas has a positive effect on firm. Coefficients for the Impact dummy variable are uniformly significant at the 5\% level at least. 
Second, the effect of US firms' internationalizations on valuation lasts only for the shortterm. Consistent with Figure 3, we find no evidence of the valuation effect in the long-term, in that coefficients on both Intermediate and Permanent dummies offer no evidence of persistent effects on Tobin's $q$. Further, we find a weak anticipatory effect in that Tobin's $q$ rises slightly one year before the internationalization, suggesting that markets positively perceive news that a US firm is undertaking its first raising of capital overseas.

Collectively, the results on the dynamics of Tobin's $q$ reported in Table 3 broadly support the segmentation theory of firms' internationalization. The observed valuation patterns are consistent with the segmentation theory prediction of a short-term positive impact, marked by an increased valuation in the period prior to the internationalization and a subsequent decline to around the original levels. Moreover, results provide additional support to debt structure theories that predict positive revaluation of the firm upon the issuance of straight debt.

\subsection{Valuation effects by firm characteristics}

The previous section suggests that US firms internationalizing by issuing offshore bonds enjoy a positive, but not enduring valuation effect in terms of Tobin's $q$. However, pooling all the internationalizing firms together might not give us a clear picture of the relationship between the firms' first internationalization activity and their valuation. To provide more detailed evidence of the impact on Tobin's $q$, we test whether the results hold when differentiating firms by various characteristics prior to the internationalization event. To do so we divide the sample into terciles, based on the levels of liquidity ratio, leverage ratio, size and age prior to the offshore bond IPO issues. The regression setup is similar to that applied in the previous section. Throughout the six models of Table 4, we report the Tobin's $q$ dynamics for the different levels of firms' liquidity and the leverage ratios, as defined by the Low, Medium, and High terciles. 


\section{Insert Table 4}

The liquidity measure used in Models $1-3$ is the quick ratio, as measured by the sum of the firms' total cash, marketable securities and accounts receivable divided by the current liabilities. The quick ratio shows the firm's ability to pay its short-term financial obligations and in our setting is the proxy for a firm's need for external funds. In Model 1 of Table 4 the Impact dummy variable record negative and significant coefficient. This suggests that firms with relatively low liquidity experience a negative short-term valuation impact. In other words, firms that are in in need of external funds prior to the offshore bond IPO transmit a low quality signal, which leads to a sharp short-term decline in their valuation. In contrast, the coefficients on the Impact dummy variable in Models 2-3 reveal that firms with a higher liquidity ratio, as expected, experience a positive effect on their valuation. Consistent with the previous findings, the valuation effect lasts for one year and does not persist in the following years.

Models 4-6 check for the valuation effects by differentiating firms based on their leverage ratio levels (as defined above) prior to internationalization. The Impact dummy variable exhibits positive and significant coefficients for Models 5 and 6, implying a positive valuation effect for relatively leveraged US firms only. Note, however, that the actual levels of debt-toequity ratios for firms included in the Medium and High terciles are around one, a characteristic of relatively safe firms; a result that confirms the previous finding of sound firms experiencing a short-term boost in their valuation in the year following the first overseas bond issue. Further, we do not find any evidence of a long-term valuation effect as Tobin's $q$ returns to around the pre-internationalization levels shortly after the initial change.

Insert Table 5 
Table 5 demonstrates that the valuation effect varies with firm-specific attributes such as size and age. Relative size is defined as the natural logarithm of book value of total assets over the average size of all issuers in the given decade. Results indicate that small and mediumsized US firms in our sample experience a short-term increase in their valuation following internationalization. The coefficients on dummy variables for some of the world's largest firms in terms of total assets are still positive, yet are insignificant. Further, throughout Models 4-6 we observe that US firms experience a short-term positive valuation effect regardless of their age at the time of the internationalization event. The magnitudes of the Impact coefficients, however, reveal that younger firms (under 22 years old at the time of an overseas bond IPO issue) experience the highest positive short-term valuation effect. Collectively these results support the notion that firms with relatively high information asymmetry are more affected by internationalization activity. This is consistent with Diamond's (1991) reputation-building assertion, and Chaplinsky and Ramchand's (2000) argument of market value being positively related to the number of informed investors and better information coverage overall.

5.2 Valuation effects by timing and location of the issue

We also test the bonding hypothesis argument that internationalization activity results in a change of corporate governance affecting firm valuation. La Porta et al. (2002) establish that US firms have the most advanced corporate governance systems in the world. The rationale behind the bonding hypothesis is that firms from countries with poor governance raise capital in markets with better corporate governance standards, the internationalization setup of US firms should not support this view, and there is a possibility of a reverse bonding hypothesis. Therefore, we expect a divergence in valuation effects between firms that decide to issue debt in developed markets with strict systems and high investor protection and those that raise 
capital in emerging markets with potentially weak structure systems and loose listing requirements. We therefore investigate the locations US firms choose to internationalize into.

\section{Insert Table 6}

In Models 1 and 2 of Table 6, we split our sample based on the location of the firms' first internationalization activity. The sample is divided into US firms undertaking debt IPOs in emerging and developed markets. The Impact dummy is significant and positive only in Model 2 (developed markets) and is insignificant in Model 1 (emerging markets). This result points to a different impact on US firms' valuations based on the location of their internationalization activity. Specifically, a positive short-term effect on Tobin's $q$ is conditional upon the US firms raising debt in other developed markets. Internationalizing into such markets with strict listing requirements, strong investor protection, and tight regulations improves a firm's valuation significantly in the short-term and, perhaps, certifies its quality. The valuation of those firms that raise capital in emerging markets remains unchanged. This finding is broadly consistent with the observation of La Porta et al. (2002) that firms in countries with weaker investor protection have a lower valuation than firms operating in environments with stronger protection and governance systems.

The evidence from Ljungqvist (1995), Helwege and Liang (1996), Pagano et al. (1998), and Santos (2006) suggests that fluctuations in the number of bond IPOs over the years are dependent on the general conditions of US economy. Thus, we create Models 3 and 4 to check for differences in the impact on firm valuations of internationalization actions that occurred during recessions and expansion periods. Specifically, Model 3 reports the impact on the valuation of US firms during the recession periods as defined by NBER, while Model 4 examines the impact during the expansion times. The results suggest that US firms issuing 
overseas bond IPOs during a recession suffer a short-term negative valuation impact. Specifically, each of the dummy variables tracing the dynamics of the impact on valuation after the internationalization show negative coefficients. In contrast, we find positive short-term anticipation and impact effects for US firms internationalizing during period of expansion for the US economy. Therefore, US firms internationalizing by issuing bonds overseas seem at least in the short-term to benefit from favorable US market conditions.

A notable feature of the current sample is that only 32 firms undertook their overseas bond IPO during recession periods and only 17 of 168 firms issued bonds in emerging markets over the sample period. This may cast some doubts on the aforementioned results.

\section{Robustness tests}

We also perform a number of supplementary robustness checks of various types. First, we ensure that the main results of the paper are not sample-specific. The sample of this study starts in January 1984, but the majority of the firms in the sample were founded in the first half of the twentieth century, meaning that for some of the firms the data on the early years of their financial operations is somewhat limited. While we do manually screen each firm against the pre-sample foreign market entries, a possible concern is that we mistakenly coded some firms as new issuers when in fact the firm had already been internationalized prior to 1984. To guard against this mistake and to eliminate the left-censoring issue of survival analysis arising from the properties of the SDC database, we: (i) re-estimate our models starting from 1987, when the peak in the number of internationalizations seems to have disappeared; (ii) we repeat the empirical analysis with firms entered onto Compustat after January 1984. Imposing these restrictions produced a sample shorter than the original by about a third and two thirds, respectively. Nevertheless, most of the test estimates are similar to the counterpart values in the benchmark specifications of the previous sections. 
Second, we check the reliability of our empirical strategy and rule out some of the alternative explanations of our results. The outcome variable in the survival analysis in Section 4 is an age of the firm coded based on the appearance of the firm in Compustat (which starts in 1950), which results in left-truncated estimates. Alternatively, to make sure that such truncation does not affect results, we redefine the age variable using the CRSP appearance date and trace the firm age as far back as 1925 . Additionally, we check that the results of the survival analysis hold when we impose restrictions on the underlying distribution of the outcome variable and estimate parametric models with Weibull and Gompertz distributions.

In addition, we check that the observed valuation effect is robust against an alternative proxy for Tobin's $q-$ the relative Tobin's q- that essentially is the firm's Tobin's $q$ divided by the average $q$ of all the firms in the USA in the same year. We also check that market timing theory is unable to fully explain the results for the observed dynamics of valuation around the initial offshore bond offerings. Market timing theory predicts that firms raise capital abroad to exploit hot markets and temporarily high prices for their securities (Errunza and Miller, 2000; Henderson et al., 2006). Accordingly, observed patterns in overseas bond offerings (Figure 1), in conjunction with procyclicality in debt-equity financing for large firms (Covas and Den Haan, 2011), may imply that the observed positive valuation effect in Table 3 could occur simply because of hot market valuation at times when firms are trying to explore favorable bond market conditions and issue debt. To ensure that market timing does not completely account for an observed effect, we additionally control for average industry Tobin's $q$, alongside the return and the price-earnings ratio of the S\&P 500 index. The inclusion of these controls does not alter the results on the valuation effect.

\section{Conclusions}


This paper examines the dynamics of the valuations of firms response to initial offshore bond issuance by US firms to provide empirical evidence on the validity of some important internationalization and debt structure theories. The empirical study employs a comprehensive sample of US firms that have internationalized by issuing debt in foreign markets over the 31year period from 1984 to 2014 . The findings suggest that internationalization conveys positive information to the market, reflected in an improvement to a firm's valuation in the short-term. Robustness checks indicate that the positive valuation effect is invariant to the introduction of firm specific controls, the state of market, the industry of the issuer and the alternative measure of valuation. Further, the valuation effect alters depending on the time and location of the issuance and the pre-internationalization financial condition of the firm. Additionally, we find that firms with in need of external funds prior to the debt offer, indicated by low profitability and lack of internal funds, accelerate the offshore public debt market entry.

The main finding that overseas corporate debt offerings exert a positive valuation effect of lends support to the predictions of (i) models of debt financing choice premised on the resolution of asymmetries of information, the reduced agency costs and the positive signaling of a leverage-increasing capital structure change, and (ii) the segmentation theory of internationalization that predicates an interim valuation effect. We also find that positive revaluation conditional upon internationalizing in developed markets supports signaling models (e.g., Ross, 1977), suggesting value increasing benefits of gaining access to highquality markets. Further, the heterogeneity in the valuation effect between relatively established and relatively small and young firms is consistent with Diamond's (1991) reputation-developing assertion, implying less incidence of information asymmetry for older firms.

To conclude, it is important to notice that the practice of raising international capital through issuing debt is growing rapidly, and financial internationalization is becoming a 
multidirectional phenomenon as US firms internationalize into an increasing variety of markets. As more data becomes available, future research could further investigate the causes and effects of US firms' foreign capital raisings. One direction for future research would be to explore the potential for a reverse bonding hypothesis, and the rationale behind internationalizations into markets with relatively poor corporate governance standards. Finally, it would also be useful to explore to what extent raising capital overseas affects the competitiveness of the domestic and foreign financial markets.

\section{References}

Albuquerque, R., and Wang, N., 2008. Agency conflicts, investment, and asset pricing. Journal of Finance 63, 1-40.

Alexander, G., Eun, C., and Janakiramanan, S., 1987. Asset pricing and dual listing on foreign capital markets: A note. Journal of Finance 42, 151-158.

Berger, P., Li F., and Wong, M., 2005. The Impact of Sarbanes-Oxley on Cross-listed Companies. University of Chicago. Working Paper.

Black, F., 1974. International capital market equilibrium with investment barriers. Journal of Financial Economics 1, 337-352.

Cantillo, M., and Wright, J., 2000. How do firms choose their lenders? An empirical investigation. Review of Financial Studies 13, 155-189.

Caprio, G., Laeven, L., and Levine, R., 2008. Governance and bank valuation. Journal of Financial Intermediation 16, 584-617.

Chaplinsky, S., and Ramchand, L., 2000. The impact of global equity offerings. Journal of Finance 55, 2767-2789.

Coffee, J., 2002. Racing towards the top: The impact of cross-listings and stock market competition on international corporate governance. Columbia Law Review 102, 17571831 .

Covas, F., and Den Haan, W., 2011. The cyclical behavior of debt and equity finance. American Economic Review 101, 877-899.

Cox, D., 1972. Regression models and life-tables (with discussion). Journal of the Royal Statistical Society 34, 187-220. 
Datta, S., Iskandar-Datta, M., and Patel, A., 2000. Some evidence on the uniqueness of initial public debt offerings. Journal of Finance 55, 715-743.

Diamond, D., 1991. Monitoring and reputation: The choice between bank loans and directly placed debt. Journal of Political Economy 99, 689-721.

Doidge, C., Karolyi, A., and Stulz, R., 2004. Why are firms that list in the U.S. worth more? Journal of Financial Economics 71, 205-238.

Domowitz, I., Glen, J., and Madhavan, A., 1998. International cross-listing and order flow migration: Evidence from an emerging market. Journal of Finance 53, 2001-2027.

Durnev, A., and Kim, E., 2005. To steal or not to steal: Firm attributes, legal environment, and valuation. Journal of Finance 60, 1461-1493.

Eckbo, E., 1986. Valuation effects of corporate debt offerings. Journal of Financial Economics $15,119-151$.

Engel, E., Hayes, R., and Wang, X., 2007. The Sarbanes-Oxley Act and firms' going-private decisions. Journal of Accounting and Economics 44, 116-145.

Errunza, V., and Losq, E., 1985. International asset pricing under mild segmentation: Theory and tests. Journal of Finance 40, 105-124.

Errunza, V., and Miller, D., 2000. Market segmentation and the cost of capital in international equity markets. Journal of Financial and Quantitative Analysis 35, 577-600.

Foerster, S., and Karolyi, A., 1999. The effects of market segmentation and investor recognition on asset prices: Evidence from foreign stocks listing in the United States. Journal of Finance 54, 981-1013.

Gozzi, J., Levine, R., and Schmukler, S., 2008. Internationalization and the evolution of corporate valuation. Journal of Financial Economics 88, 607-632.

Gozzi, J., Levine, R., and Schmukler, S., 2010. Patterns of international capital raisings. Journal of International Economics 80, 45-57.

Hale, G., and Santos, J., 2008. The decision to first enter the public bond market: The role of firm reputation, funding choices, and bank relationships. Journal of Banking and Finance 32, 1928-1940.

Heinkel, R., 1982. A theory of capital structure relevance under imperfect information. Journal of Finance 37, 1141-1150.

Helwege, J., and Liang, N., 1996. Is there a pecking order? Evidence from a panel of IPO firms. Journal of Financial Economics 40, 429-458.

Henderson, B., Jegadeesh, N., and Weisbach, M., 2006. World markets for raising new capital. Journal of Financial Economics 82, 63-101. 
Jensen, M., and Meckling, W., 1976. Theory of the firm: Managerial behavior, agency costs and ownership structure, Journal of Financial Economics 3, 305-360.

Johnson, S., 1997. An empirical analysis of the determinants of corporate debt ownership structure. Journal of Financial and Quantitative Analysis 32, 47-69.

Karolyi, A., 2006. The World of cross-listings and cross-listings of the world: Challenging conventional wisdom. Review of Finance 10, 99-152.

Klein, P., 2017. Do Shareholders Value Bond Offerings? A Meta-Analysis. University of Strasbourg. Working Paper.

Kraus, A., and Litzenberger, R., 1973. A state-preference model of optimal financial leverage. Journal of Finance 28, 911-922.

Krishnaswami, S., Spindt, P., and Subramaniam, V., 1999. Information asymmetry, monitoring, and the placement structure of corporate debt. Journal of Financial Economics 51, 407-434.

La Porta, R., Lopez-de-Silanes, F., Shleifer, A., and Vishny, R., 2002. Investor protection and corporate valuation. Journal of Finance 57, 1147-1170.

Lan, Y., and Wang, N., 2004. Investor protection and investment. Columbia University. Working Paper.

Levine, R., and Schmukler, S., 2006. Internationalization and stock market liquidity. Review of Finance 10, 153-187.

Licht, A., 2003. Cross-listing and corporate governance: Bonding or avoiding? Chicago Journal of International Law 4, 141-163.

Ljungqvist, A., 1995. When do firms go public? Poisson evidence from Germany. University of Oxford.Working paper.

Marosi, A., and Massoud, N., 2007. Why do firms go dark? Journal of Financial and Quantitative Analysis 42, 421-442.

Miller, M., 1977. Debt and taxes. Journal of Finance 32, 261-275.

Miller, M. and Rock, K., 1985. Dividend policy under asymmetric information. Journal of Finance 40, 1031-1051.

Modigliani, F. and Miller, M., 1958. The cost of capital, corporation finance, and the theory of investment. American Economic Review 48, 261-297.

Myers, S., and Majluf, N., 1984. Corporate financing and investment decisions when firms have information that investors do not have. Journal of Financial Economics 13, 187221. 
Pagano, M., Panetta, F., and Zingales, L., 1998. Why do companies go public? An empirical analysis. Journal of Finance 53, 27-64.

Pagano, M., Roell, A., and Zechner, J., 2002. The geography of equity listing: why do companies list abroad? Journal of Finance 57, 2651-2694.

Peristiani, S., and Santos, J., 2010. Has the US bond market lost its edge to the Eurobond market? International Review of Finance 10, 149-183.

Pinegar, J., and Ravichandran, R., 2003. U.S. investors' perceptions of corporate control in Mexico: Evidence from sibling ADRs. Journal of Financial and Quantitative Analysis $38,213-230$.

Reese Jr., W., and Weisbach, M., 2002. Protection of minority shareholder interests, crosslistings in the United States, and subsequent equity offerings. Journal of Financial Economics 66, 65-104.

Ross, S., 1977. The determination of financial structure: The incentive signaling approach. Bell Journal of Economics 8, 23-40.

Santos, J., 2006. Why firm access to the bond market differs over the business cycle: A theory and some evidence. Journal of Banking and Finance 30, 2715-2736.

Siegel, J., 2004. Can foreign firms bond themselves effectively by renting U.S. securities laws? Journal of Financial Economics 75, 319-359.

Solnik, B., 1974. Why not diversify internationally rather than domestically? Financial Analysts Journal 30, 48-54.

Stapleton, R., and Subrahmanyam, M., 1977. Market imperfections, capital market equilibrium, and corporate finance. Journal of Finance 32, 307-319.

Stein, J., 1992. Convertible bonds as backdoor equity financing. Journal of Financial Economics 32, 3-22

Stulz, R., 1999. Globalization of equity markets and the cost of capital. Journal of Applied Corporate Finance 12, 1-12.

Titman, S., and Trueman, B., 1986. Information quality and the valuation of new issues. Journal of Accounting and Economics 8, 159-172.

Tobin, J., Brainard, W., 1977. Asset markets and the cost of capital. In: Balassa, B., Nelson, R. (Eds.), Economic Progress, Private Values, and Public Policy. North Holland, Amsterdam, 235-262.

Zingales, L., 2007. Is the U.S. capital market losing its competitive edge? ECGI- Finance Working Paper No. 192/2007. 
Table 1. Basic statistics

This table reports the summary statistics for US firms that internationalize by issuing bonds abroad during the period 1984-2015. The sample is divided into four decades, namely the 1980s, 1990s, 2000s and 2010s, based on the dates of bond issues by firms. Panel A displays the number of first time offshore bond issues by all US firms (including financial firms) with the average dollar amount of issues, and the total number of all following offshore bond issues with the average dollar amounts per issue. Panel B reports the specific characteristics of US firms (excluding financial firms) one year prior the offshore bond IPO by decade. The averages, and the minimum and maximum values are reported for the following firm attributes: age, size, profitability, investments, liquidity and leverage.

Panel A: Number and amount of offshore bond IPOs by decade

Offshore bond IPOs

Number of first issues

Average amount of first issues $(\$$ mill)

Total number of issues

Average amount of all issues (\$ mill)
$80 \mathrm{~s}$

78

21

66

33

133.10

282.57

530.41

661.98

276

214

851

211

$234.09 \quad 1065.36$

846.46

Panel B: Firm characteristics at time of first offshore bond issue by decade (non-financials)

\begin{tabular}{|c|c|c|c|c|c|}
\hline \multicolumn{2}{|l|}{ Firm characteristic } & $80 \mathrm{~s}$ & $90 \mathrm{~s}$ & 00s & $10 \mathrm{~s}$ \\
\hline \multirow{3}{*}{ Age } & average & 29 & 27 & 31 & 28 \\
\hline & $\min$ & 1 & 3 & 3 & 7 \\
\hline & $\max$ & 38 & 49 & 54 & 63 \\
\hline \multirow{3}{*}{ Size (\$ mill) } & average & 7657 & 10632 & 22409 & 35621 \\
\hline & $\min$ & 189 & 218 & 531 & 2110 \\
\hline & $\max$ & 46176 & 80292 & 284421 & 274098 \\
\hline \multirow{3}{*}{ Profitability } & average & 7.51 & 3.17 & 6.76 & 8.64 \\
\hline & $\min$ & -23.82 & -57.72 & -8.76 & -0.47 \\
\hline & $\max$ & 17.70 & 18.93 & 24.03 & 24.54 \\
\hline \multirow{3}{*}{ Investments } & average & 0.63 & 0.60 & 0.58 & 0.69 \\
\hline & $\min$ & 0.00 & 0.11 & 0.00 & 0.52 \\
\hline & $\max$ & 0.84 & 0.93 & 0.85 & 0.90 \\
\hline \multirow{3}{*}{ Liquidity (ln Quick) } & average & 1.02 & 1.16 & 1.24 & 2.02 \\
\hline & $\min$ & 0.03 & 0.02 & 0.07 & 0.08 \\
\hline & $\max$ & 3.98 & 6.37 & 8.60 & 5.08 \\
\hline \multirow{3}{*}{ Leverage } & average & 0.34 & 0.75 & 0.62 & 0.60 \\
\hline & $\min$ & 0.01 & 0.08 & 0.09 & 0.09 \\
\hline & $\max$ & 1.05 & 7.05 & 3.12 & 2.33 \\
\hline
\end{tabular}


Table 2. Timing and firm characteristics

This table presents coefficient estimates of semiparametric Cox proportional hazards regression models. The outcome variable in each of the models is the firm's age and the failure event is the offshore bond IPO. The outcome variable is estimated against the set of explanatory variables, namely, Tobin's q, Investments-to-Assets, Quick ratio, ROA, Leverage, Size, Offshore bond market conditions, and the Recession indicator. We use a $\chi^{2}$ test to assess whether the assumption of proportional hazard is appropriate.

\begin{tabular}{|c|c|c|c|c|c|c|c|}
\hline & (1) & (2) & (3) & (4) & (5) & (6) & (7) \\
\hline \multirow[t]{2}{*}{ Tobin's q } & 0.009 & & & & & & 0.016 \\
\hline & $(0.145)$ & & & & & & $(0.228)$ \\
\hline \multirow[t]{2}{*}{ Investments/Assets } & & $0.234 * * *$ & & & & $0.316 * * *$ & $0.259 * * *$ \\
\hline & & $(3.116)$ & & & & $(3.948)$ & $(3.002)$ \\
\hline \multirow[t]{2}{*}{ ROA } & & & $-0.026 * * *$ & & & $-0.024 * * *$ & $-0.021 * * *$ \\
\hline & & & $(-5.208)$ & & & $(-4.283)$ & $(-3.379)$ \\
\hline \multirow[t]{2}{*}{ Quick ratio } & & & & $-0.061 * *$ & & $-0.087 * *$ & $-0.131 * *$ \\
\hline & & & & $(-2.009)$ & & $(-2.115)$ & $(-2.200)$ \\
\hline \multirow[t]{2}{*}{ Leverage ratio } & & & & & -0.010 & & -0.001 \\
\hline & & & & & $(-0.897)$ & & $(0.050)$ \\
\hline \multirow[t]{2}{*}{ Size (Log of Total Assets) } & & & & & & 0.103 & 0.014 \\
\hline & & & & & & $(1.528)$ & $(0.199)$ \\
\hline \multirow[t]{2}{*}{ Offshore bond market } & & & & & & & $0.016 * * *$ \\
\hline & & & & & & & $(7.496)$ \\
\hline \multirow[t]{2}{*}{ Recession indicator } & & & & & & & -0.177 \\
\hline & & & & & & & $(-0.751)$ \\
\hline No. of Observations & 2256 & 2359 & 2256 & 2114 & 2359 & 2013 & 2013 \\
\hline $\operatorname{LR} \chi^{2}$ & 0.07 & 10.15 & 13.49 & 13.49 & 0.01 & 29.71 & 87.76 \\
\hline Prob. $>\chi^{2}$ & 0.80 & 0.00 & 0.79 & 0.00 & 0.92 & 0.00 & 0.00 \\
\hline
\end{tabular}




\section{Table 3. Internationalization and firm valuation}

The dependent variable is Tobin's $q$. The Anticipatory dummy equals one for the year prior to the first overseas bond issue by US firm and zero otherwise. The Impact dummy captures the impact effect of the internationalization and takes the value of one in the year of bond issue and zero otherwise, while Intermediate represents a dummy variable that equals one for the year after the first offshore bond issue and zero otherwise. The Permanent dummy equals one in the period starting from two years after the first offshore bond issue event and remains one throughout all of the subsequent years in the sample. All models include firm and year dummies, albeit not reported in the table. A firm is considered international if it raises capital in international markets at least once. The regressions are estimated with standard errors clustered by firm. The constant is estimated, albeit not reported in the table. T-statistics are reported in brackets. $*, * *, * * *$ denote statistical significance at the $10 \%, 5 \%$ and $1 \%$ levels respectively. The estimated equation is the following:

$$
T_{i, t}^{I}=\alpha_{0}+\beta_{1} A n t_{i, t}+\beta_{2} I m p_{i, t}+\beta_{3} I n t_{i, t}+\beta_{4} \operatorname{Per}_{i, t}+\beta_{5} S_{i, t}+\beta_{6} S G_{i, t}+\beta_{7} L_{i, t}+\beta_{8} n_{j}+\beta_{9} \tau_{t}+\varepsilon_{i, t}
$$

\begin{tabular}{|c|c|c|c|c|c|c|}
\hline \multirow[b]{3}{*}{ Anticipatory } & \multicolumn{6}{|c|}{ Dependent Variable: Tobin's $q$} \\
\hline & $(1)$ & (2) & (3) & $(4)$ & $(5)$ & $(6)$ \\
\hline & $\begin{array}{c}0.079 \\
(1.450)\end{array}$ & & & & $\begin{array}{l}0.108 * \\
(1.814)\end{array}$ & $\begin{array}{c}0.117 * \\
(1.904)\end{array}$ \\
\hline Impact & & $\begin{array}{c}0.040 * * \\
(2.035)\end{array}$ & & & $\begin{array}{c}0.078 * * * \\
(2.701)\end{array}$ & $\begin{array}{c}0.093 * * * \\
(2.843)\end{array}$ \\
\hline Intermediate & & & $\begin{array}{c}-0.012 \\
(-0.317)\end{array}$ & & & $\begin{array}{c}0.036 \\
(0.906)\end{array}$ \\
\hline Permanent & & & & $\begin{array}{c}0.050 \\
(0.900)\end{array}$ & & \\
\hline Size (Log of Total Assets) & $\begin{array}{c}-1.423 * * * \\
(-4.116)\end{array}$ & $\begin{array}{c}-1.431 * * * \\
(-4.134)\end{array}$ & $\begin{array}{c}-1.427 * * * \\
(-4.126)\end{array}$ & $\begin{array}{c}-1.435 * * * \\
(-4.104)\end{array}$ & $\begin{array}{c}-1.427 * * * \\
(-4.118)\end{array}$ & $\begin{array}{c}-1.429 * * * \\
(-4.119)\end{array}$ \\
\hline Log of (Sales Growth) & $\begin{array}{c}0.278 * * \\
(2.092)\end{array}$ & $\begin{array}{c}0.285^{* *} \\
(2.127)\end{array}$ & $\begin{array}{c}0.286 * * \\
(2.119)\end{array}$ & $\begin{array}{c}0.303 * * \\
(2.158)\end{array}$ & $\begin{array}{c}0.268 * * \\
(1.990)\end{array}$ & $\begin{array}{c}0.271 * * \\
(2.006)\end{array}$ \\
\hline Leverage & $\begin{array}{c}-0.002 \\
(-0.629)\end{array}$ & $\begin{array}{c}-0.003 \\
(-0.882)\end{array}$ & $\begin{array}{c}-0.003 \\
(-0.794)\end{array}$ & $\begin{array}{c}-0.003 \\
(-0.829)\end{array}$ & $\begin{array}{c}-0.003 \\
(-0.780)\end{array}$ & $\begin{array}{c}-0.003 \\
(-0.805)\end{array}$ \\
\hline Firm Dummies & Yes & Yes & Yes & Yes & Yes & Yes \\
\hline Year Dummies & Yes & Yes & Yes & Yes & Yes & Yes \\
\hline R-squared & 0.70 & 0.78 & 0.71 & 0.70 & 0.78 & 0.78 \\
\hline
\end{tabular}


Table 4. Valuation effects by firm's liquidity and indebtedness

The dependent variable is Tobin's $q$. The sample is divided into Low, Medium and High terciles based on the liquidity ratio and leverage ratio of the US firm at the time of first offshore bond issues. The Anticipatory dummy equals one for the year prior to the first overseas bond issue by US firm and zero otherwise. The Impact dummy captures the impact effect of the internationalization and takes the value of one in the year of bond issue and zero otherwise, while Intermediate represents a dummy variable that equals one for the year after the first offshore bond issue and zero otherwise. All models include firm and year dummies, albeit not reported in the table. A firm is considered international if it raises capital in international markets at least once. The regressions are estimated with standard errors clustered by firm. The constant is estimated, albeit not reported in the table. T-statistics are reported in brackets. *,**, *** denote statistical significance at the $10 \%, 5 \%$ and $1 \%$ levels respectively. The estimated equation is the following:

$$
T_{i, t}^{I}=\alpha_{0}+\beta_{1} A n t_{i, t}+\beta_{2} \operatorname{Imp}_{i, t}+\beta_{3} \operatorname{Int}_{i, t}+\beta_{4} S_{i, t}+\beta_{5} S G_{i, t}+\beta_{6} L_{i, t}+\beta_{7} n_{j}+\beta_{9} \tau_{t}+\varepsilon_{i, t}
$$

\begin{tabular}{|c|c|c|c|c|c|c|}
\hline & \multicolumn{6}{|c|}{ Dependent Variable: Tobin's q } \\
\hline & \multicolumn{3}{|c|}{ Liquidity } & \multicolumn{3}{|c|}{ Leverage } \\
\hline & Low & Med & High & Low & Med & High \\
\hline & $(1)$ & $(2)$ & (3) & (4) & $(5)$ & $(6)$ \\
\hline \multirow[t]{2}{*}{ Anticipatory } & -0.060 & 0.104 & 0.076 & -0.053 & 0.073 & $0.143 * *$ \\
\hline & $(-1.623)$ & $(1.425)$ & $(0.382)$ & $(-0.221)$ & $(0.976)$ & $(2.179)$ \\
\hline \multirow[t]{2}{*}{ Impact } & $-0.075 * *$ & $0.195 * * *$ & 0.047 & -0.097 & $0.124 * * *$ & $0.121 * *$ \\
\hline & $(-2.564)$ & $(3.097)$ & $(0.463)$ & $(-0.761)$ & $(2.847)$ & $(2.523)$ \\
\hline \multirow[t]{2}{*}{ Intermediate } & -0.037 & $0.117 *$ & -0.059 & $(-0.052)$ & 0.056 & $0.098^{*}$ \\
\hline & $(-0.950)$ & $(1.937)$ & $(-0.407)$ & $(-0.260)$ & $(1.491)$ & $(1.983)$ \\
\hline \multirow[t]{2}{*}{ Size (Log of Total Assets) } & $-0.399 * * *$ & $-0.622 * *$ & $-1.982 * * *$ & $-3.207 * * *$ & $-0.654 * * *$ & -0.168 \\
\hline & $(-4.583)$ & $(-2.536)$ & $(-3.886)$ & $(-3.742)$ & $(-6.290)$ & $(-1.426)$ \\
\hline \multirow[t]{2}{*}{ Log of (Sales Growth) } & 0.022 & $0.491 * * *$ & 0.528 & $1.383^{*}$ & $0.227^{*}$ & -0.249 \\
\hline & $(0.426)$ & $(6.721)$ & (1.024) & $(1.972)$ & (1.789) & $(-1.27)$ \\
\hline \multirow[t]{2}{*}{ Leverage } & 0.011 & -0.005 & -0.001 & 0.016 & -0.010 & -0.002 \\
\hline & $(0.341)$ & $(-1.176)$ & $(-0.247)$ & (1.348) & $(-0.075)$ & $(-1.075)$ \\
\hline Firm Dummies & Yes & Yes & Yes & Yes & Yes & Yes \\
\hline Year Dummies & Yes & Yes & Yes & Yes & Yes & Yes \\
\hline R-squared & 0.89 & 0.84 & 0.63 & 0.79 & 0.78 & 0.84 \\
\hline
\end{tabular}


Table 5. Valuation effects by firm's relative size and age

The dependent variable is Tobin's $q$. The sample is divided into Low, Medium and High terciles based on the age and relative size of the US firm at the time of the first offshore bond issues. The Anticipatory dummy equals one for the year prior to the first overseas bond issue by US firm and zero otherwise. The Impact dummy captures the impact effect of the internationalization and takes the value of one in the year of bond issue and zero otherwise, while Intermediate represents a dummy variable that equals one for the year after the first offshore bond issue and zero otherwise. All models include firm and year dummies, albeit not reported in the table. A firm is considered as international if it raises capital in international markets at least once. The regressions are estimated with standard errors clustered by firm. The constant is estimated, albeit not reported in the table. T-statistics are reported in brackets. *,**, *** denote statistical significance at the $10 \%, 5 \%$ and $1 \%$ levels respectively. The estimated equation is the following:

$$
T_{i, t}^{I}=\alpha_{0}+\beta_{1} A n t_{i, t}+\beta_{2} \operatorname{Imp}_{i, t}+\beta_{3} \operatorname{Int}_{i, t}+\beta_{4} S_{i, t}+\beta_{5} S G_{i, t}+\beta_{6} L_{i, t}+\beta_{7} n_{j}+\beta_{9} \tau_{t}+\varepsilon_{i, t}
$$

\begin{tabular}{|c|c|c|c|c|c|c|}
\hline & \multicolumn{6}{|c|}{ Dependent Variable: Tobin's q } \\
\hline & \multicolumn{3}{|c|}{ Relative Size } & \multicolumn{3}{|c|}{ Age } \\
\hline & Small & Med & Large & Low & Med & High \\
\hline & $(1)$ & $(2)$ & (3) & (4) & $(5)$ & $(6)$ \\
\hline Anticipatory & $\begin{array}{c}0.115 \\
(1.251)\end{array}$ & $\begin{array}{c}0.025 \\
(0.301)\end{array}$ & $\begin{array}{c}0.119 \\
(1.585)\end{array}$ & $\begin{array}{c}0.261 \\
(1.590)\end{array}$ & $\begin{array}{l}0.071 * * \\
(2.302)\end{array}$ & $\begin{array}{l}0.154 * \\
(1.700)\end{array}$ \\
\hline Impact & $\begin{array}{c}0.096 * * \\
(2.194)\end{array}$ & $\begin{array}{c}0.060 * * * \\
(2.700)\end{array}$ & $\begin{array}{c}0.057 \\
(1.297)\end{array}$ & $\begin{array}{l}0.200 * \\
(1.698)\end{array}$ & $\begin{array}{c}0.111 * * * \\
(4.383)\end{array}$ & $\begin{array}{l}0.113^{*} \\
(1.693)\end{array}$ \\
\hline Intermediate & $\begin{array}{c}0.078 \\
(1.318)\end{array}$ & $\begin{array}{c}-0.030 \\
(-0.377)\end{array}$ & $\begin{array}{c}0.048 \\
(0.540)\end{array}$ & $\begin{array}{c}0.007 \\
(0.056)\end{array}$ & $\begin{array}{c}0.096 * * * \\
(3.079)\end{array}$ & $\begin{array}{c}0.024 \\
(0.247)\end{array}$ \\
\hline Size (Log of Total Assets) & $\begin{array}{c}-0.161 * * \\
(-2.068)\end{array}$ & $\begin{array}{c}-3.189 * * * \\
(-5.115)\end{array}$ & $\begin{array}{l}-0.806^{*} \\
(-1.933)\end{array}$ & $\begin{array}{c}-1.964 * * * \\
(-2.715)\end{array}$ & $\begin{array}{c}-0.107 \\
(-0.890)\end{array}$ & $\begin{array}{c}-1.118 * * * \\
(-3.983)\end{array}$ \\
\hline Log of (Sales Growth) & $\begin{array}{c}0.161 \\
(0.927)\end{array}$ & $\begin{array}{c}1.514 * * * \\
(3.649)\end{array}$ & $\begin{array}{c}-0.043 \\
(-0.397)\end{array}$ & $\begin{array}{c}0.486 \\
(0.721)\end{array}$ & $\begin{array}{l}0.198 * \\
(1.741)\end{array}$ & $\begin{array}{c}0.389 * * \\
(2.116)\end{array}$ \\
\hline Leverage & $\begin{array}{c}-0.005 \\
(-1.377)\end{array}$ & $\begin{array}{c}-0.258 \\
(-0.734)\end{array}$ & $\begin{array}{c}-0.061 \\
(-0.734)\end{array}$ & $\begin{array}{c}0.001 \\
(0.147)\end{array}$ & $\begin{array}{c}-0.015 * * * \\
(-5.500)\end{array}$ & $\begin{array}{c}-0.107 \\
(-0.365)\end{array}$ \\
\hline Firm Dummies & Yes & Yes & Yes & Yes & Yes & Yes \\
\hline Year Dummies & Yes & Yes & Yes & Yes & Yes & Yes \\
\hline R-squared & 0.67 & 0.83 & 0.77 & 0.74 & 0.91 & 0.84 \\
\hline
\end{tabular}


Table 6. Valuation effects by location and economic conditions

The dependent variable is Tobin's $q$. The sample is divided into emerging/developed countries based on the location of the first time offshore bond issues by US firms. Additionally, the valuation impact is examined during the recession and expansion periods. The Anticipatory dummy equals one for the year prior to the first overseas bond issue by the US firm and zero otherwise. The Impact dummy captures the impact effect of the internationalization and takes the value of one in the year of bond issue and zero otherwise, while Intermediate represents a dummy variable that equals one for the year after the first offshore bond issue and zero otherwise. All models include firm and year dummies, albeit not reported in the table. A firm is considered as international if it raises capital in international markets at least once. The regressions are estimated with standard errors clustered by firm. The constant is estimated, albeit not reported in the table. T-statistics are reported in brackets. $*, * *, * *$ denote statistical significance at the $10 \%, 5 \%$ and $1 \%$ levels respectively. The estimated equation is:

$$
T_{i, t}^{I}=\alpha_{0}+\beta_{1} A n t_{i, t}+\beta_{2} I m p_{i, t}+\beta_{3} I n t_{i, t}+\beta_{4} S_{i, t}+\beta_{5} S G_{i, t}+\beta_{6} L_{i, t}+\beta_{7} n_{j}+\beta_{9} \tau_{t}+\varepsilon_{i, t}
$$

\begin{tabular}{|c|c|c|c|c|}
\hline & \multicolumn{4}{|c|}{ Dependent Variable: Tobin's $q$} \\
\hline & \multicolumn{2}{|c|}{ Emerging vs Developed } & \multicolumn{2}{|c|}{ Recession } \\
\hline & Emerging & Developed & During & Outside \\
\hline & $(1)$ & $(2)$ & $(3)$ & (4) \\
\hline \multirow[t]{2}{*}{ Anticipatory } & -0.020 & $0.125^{*}$ & -0.368 & $0.093^{*}$ \\
\hline & $(-0.180)$ & $(1.723)$ & $(-1.501)$ & $(1.677)$ \\
\hline \multirow[t]{2}{*}{ Impact } & 0.277 & $0.086^{* *}$ & $-0.293 * *$ & $0.07 * *$ \\
\hline & $(1.540)$ & $(2.534)$ & $(-2.257)$ & $(2.571)$ \\
\hline \multirow[t]{2}{*}{ Intermediate } & 0.085 & 0.032 & $-0.173 * * *$ & 0.031 \\
\hline & $(0.391)$ & $(0.747)$ & $(-3.180)$ & $(0.913)$ \\
\hline \multirow[t]{2}{*}{ Size (Log of Total Assets) } & $-0.876^{* * *}$ & $-1.486 * * *$ & -0.019 & $-0.368 * * *$ \\
\hline & $(-2.992)$ & $(-4.015)$ & $(-0.138)$ & $(-4.824)$ \\
\hline \multirow[t]{2}{*}{ Log of (Sales Growth) } & 0.409 & $0.387 * *$ & 0.438 & 0.247 \\
\hline & $(0.602)$ & $(2.024)$ & $(0.895)$ & $(3.826)$ \\
\hline \multirow[t]{2}{*}{ Leverage } & $-0.482 * * *$ & -0.003 & $-0.100 * *$ & -0.003 \\
\hline & $(-4.294)$ & $(-0.890)$ & $(-2.321)$ & $(-1.421)$ \\
\hline Firm Dummies & Yes & Yes & Yes & Yes \\
\hline Year Dummies & Yes & Yes & Yes & Yes \\
\hline R-squared & 0.88 & 0.69 & 0.14 & 0.80 \\
\hline
\end{tabular}




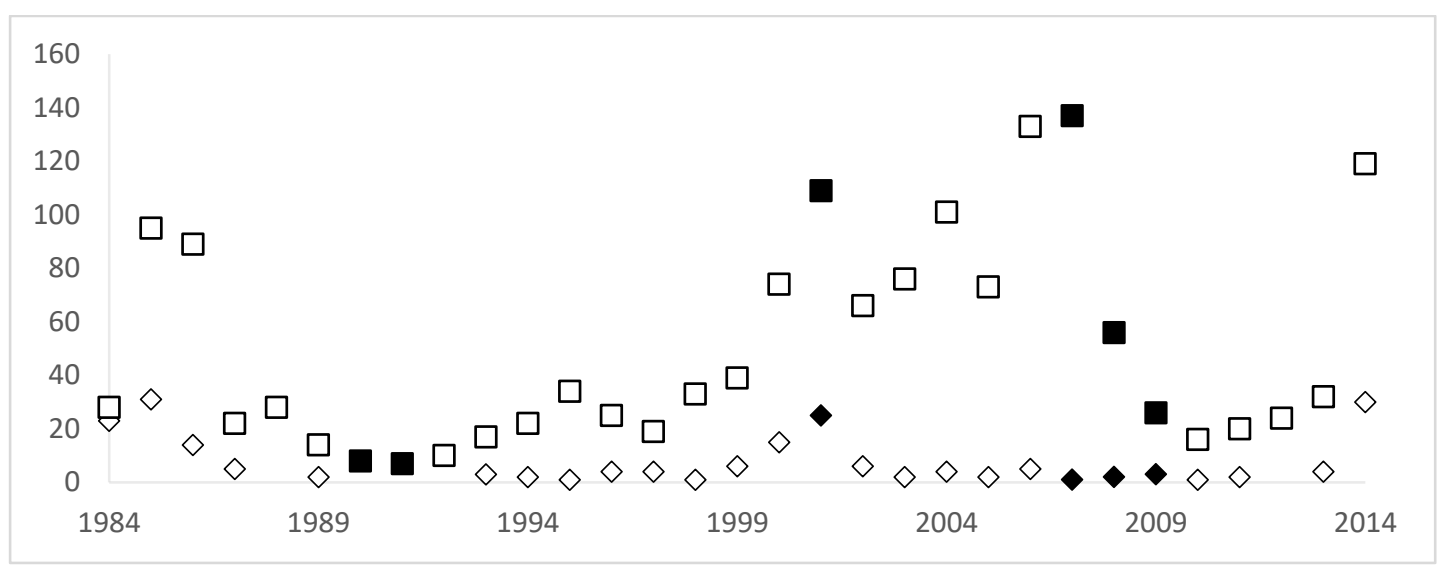

Figure 1. Number of all (squares) and first (diamonds) offshore public bond issues over sample period. Note: markers are filled if at least one issue occurs during recession periods, as defined by NBER. 

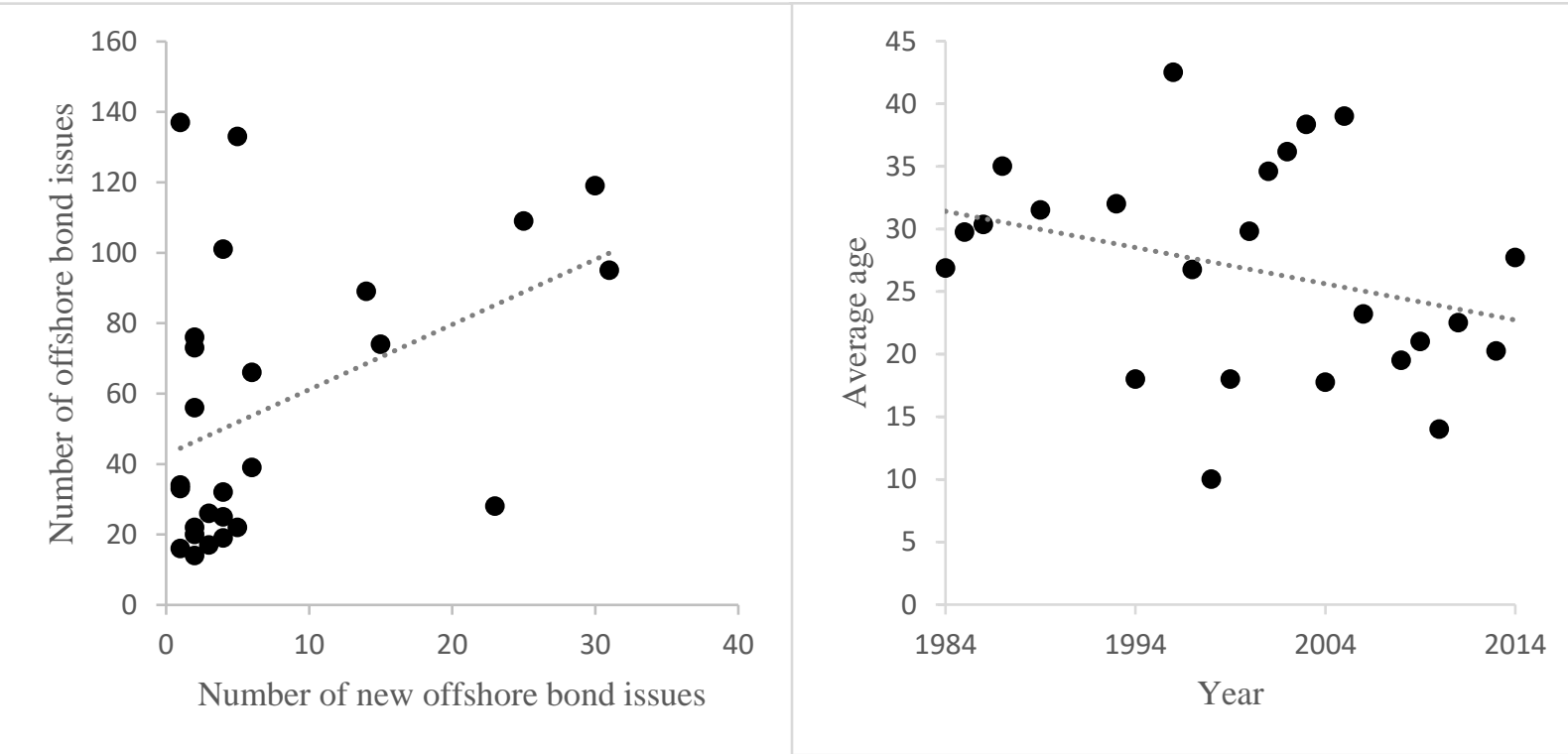

Figure 2. First offshore bond IPOs vs. total number offshore bond issues in the same year (left-hand side) and average age of firms that internationalize over sample period (right-hand side). 


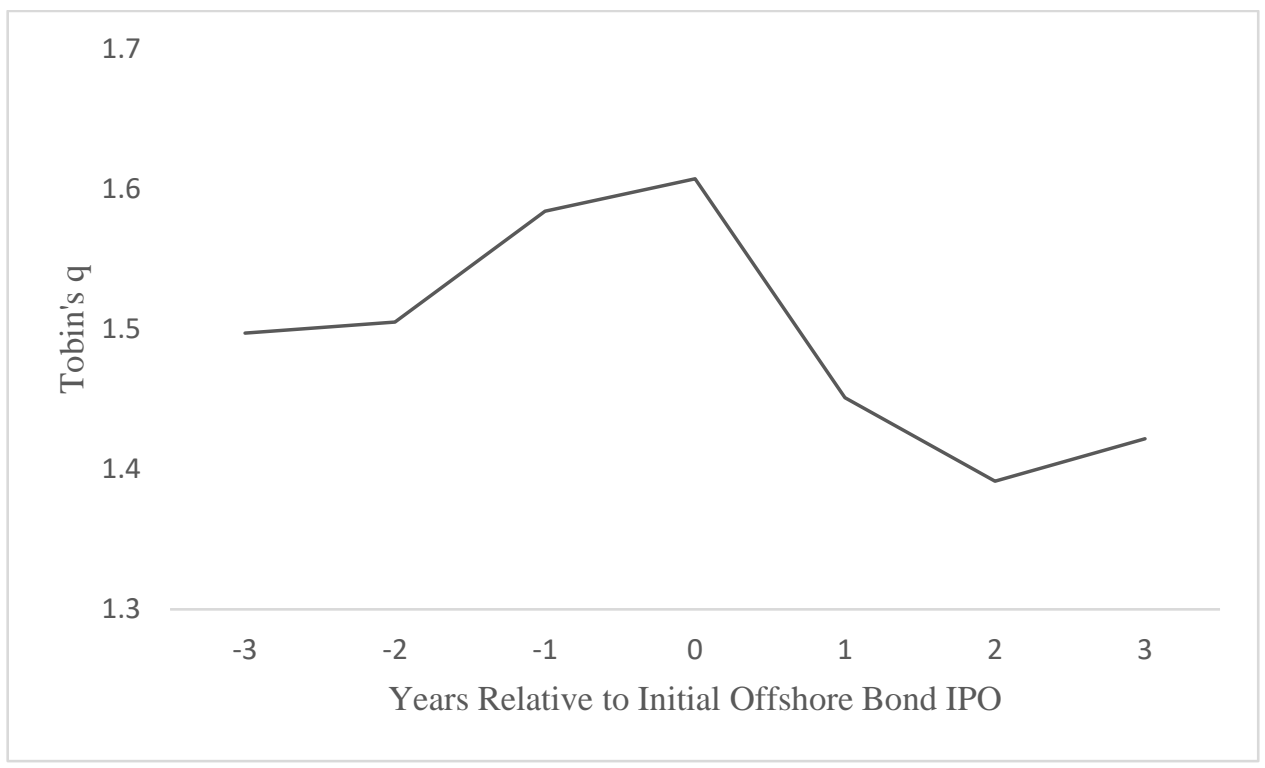

Figure 3. Dynamics of average Tobin's $q$. Graph plots the dynamic of average Tobin's q of the firms that undertake their first offshore bond IPO (date zero). 